\title{
EFFECTS OF CORPORATE TAX REFORMS ON SMES' INVESTMENT DECISIONS UNDER THE PARTICULAR CONSIDERATION OF INFLATION
}

\author{
CHANG WOON NAM \\ DOINA MARIA RADULESCU
}

CESIFO WORKING PAPER NO. 1478

CATEGORY 1: PUBLIC FinANCE

JUNE 2005

\footnotetext{
An electronic version of the paper may be downloaded

- from the SSRN website:

www.SSRN.com

- from the CESifo website: Www.CESifo.de
} 


\title{
EFFECTS OF CORPORATE TAX REFORMS ON SMES’ INVESTMENT DECISIONS UNDER THE PARTICULAR CONSIDERATION OF INFLATION
}

\begin{abstract}
Corporate tax reforms carried out in EU countries since 1980 entail lower statutory tax rates and reductions in generous tax depreciation provisions. Several countries including the UK have reduced tax rates for SMEs. This study compares incentive effects of such reforms on the SMEs' investment decisions adopting simple present value model. Ceteris paribus tax rate and depreciation rule vary in the model simulation, while the application of historical cost accounting method in inflationary phases leads to fictitious increases in nominal net present value. Apart from the construction of international ranking, country- specific patterns of reform effects are also illustrated.
\end{abstract}

JEL Code: H25, H32.

Keywords: SMEs, corporate tax reform, investment decision, inflation, EU countries.

Chang Woon Nam

Ifo Institute for Economic Research at the University of Munich

Poschingerstr. 5

81679 Munich

Germany nam@ifo.de
Doina Maria Radulescu

Ifo Institute for Economic Research at the University of Munich

Poschingerstr. 5

81679 Munich

Germany

radulescu@ifo.de 


\section{Introduction}

The vast majority of firms that operate in advanced countries are small and mediumsized enterprises (SMEs). Therefore, SMEs' competitiveness significantly affects the competitive position of the country's economy as a whole. The concentration of SMEs' activities on domestic market leads to the bounded business vision. Combined with the asymmetric information about the profit opportunities abroad, this fact tends to limit the diversification of SMEs' investments in an international context. Consequently they appear to be more directly affected by the national corporate tax reform than is the case with large multinational firms. On the other hand, SMEs have quite often been the primary target group of such an investment promotion policy (Hendricks, Amit and Whistler, 1997; Chen, Lee and Mintz, 2002; Devereux, Griffith and Klemm, 2004). According to Coyne (1995), SMEs are generally more responsive to domestic tax incentives than large ones. Taxes may play a more important role in the cost structure of SMEs because they do not have the financial and human capacity to developed sophisticated tax avoidance strategies.

Some EU countries including the UK have traditionally had lower tax rates for SMEs, whereas such a corporate tax reduction does not exist in countries like Austria, Finland and Germany at all (see Table 1). Although it is disputable, those countries that provide fiscal incentives and preferential tax treatment to SMEs claim that they (i) create a large number of jobs and (ii) enhance the level of entrepreneurship, which implies flexibility, speed, risk-taking and innovation (Chen, Lee and Mintz, 2002). A further reason for the tax policy attention paid to the SMEs is that they represent "an important breeding ground for large, profitable, tax-paying employers of the future and [experience] high growth rates in comparison to large enterprises" (Hendricks, Amit and Whistler, 1997, p. 1).

The definition of SMEs for tax purpose also differs from one country to another. In the UK SMEs are generally those firms that yield profits between GBP 50,000 and GBP 300,000 annually. For the limited years from 2000 to 2002, Ireland also had a corporate tax rate of $12.5 \%$ for SMEs. Yet the total trading income on which this reduced rate was imposed changed from $€ 63,500$ (2000) to $€ 254,000$ (2001). France has recently introduced a special tax rule for SMEs but in a rather limited manner: those companies that realise a maximum turnover of $€ 7,630,000$ and at least $75 \%$ of whose capital is continuously owned by individuals or companies satisfying the same conditions are subject to corporate tax at a reduced rate of $15 \%$ (2004) on the proportion of the taxable profit that does not exceed $€ 38,120$ (Chen, Lee and Mintz, 2002; KPMG Corporate Tax Rate Survey for various years from 2000 to 2004). 
The statutory corporate tax rate is clearly important in calculating the overall tax burden. However, this tax rate does not, in itself, establish the ultimate tax burden on the firms' investment activity. Equally crucial are the effects of the depreciation and other investment promotion provisions that determine the tax base (Sørensen, 2004). In the practice of corporate tax policy different tax depreciation rules are employed that do not typically ensure the so-called true economic depreciation (Samuelson, 1964; Sinn, 1987). Furthermore, their generosity has been extended to stimulate private investment.

On the other hand, depreciation based upon historical cost is undervalued during inflationary phases, as the real cost of depreciation of today's assets is underestimated when the asset base is measured in nominal term (Ott, 1984; Cohen and Hasset, 1999; Haufler and Schjelderup, 2000). There have been a number of attempts to estimate the current value of a capital good on the basis of indexation (Feldstein, 1979; Feldstein and Summers, 1979; Hulten and Wykoff, 1996). "Such a method would provide for equitable accounting whether inflation rates were high or low. [But] many agree that it would be too complicated to compute the rate of inflation for the multitude of different assets. The idea of using an overall index was rejected on the grounds that some assets such as computers actually [decline] in price over time and this method would bias investment towards those assets that increased in price" (Evans, 1983, p.150).

A series of corporate tax reforms carried out in EU countries (like Austria, Finland, France, Germany, Ireland and the UK) have generally entailed lower statutory tax rates and a reduction in generous tax depreciation provisions (including investment tax allowances, generous geometric-degressive as well as free and accelerated depreciation) (see Table 1 and 2). To a large extent this process has been triggered by the fierce tax competition among EU members aimed at attracting capital, in particular direct investment of multinational firms (Keen, 1991; Janeba, 1995; Haufler and Schjelderup, 2000; Devereux and Griffith, 2003).

The tax-rate-cut-cum-base-broadening reform "has interesting effects on firms' investment incentives. Most empirical research on the impact of taxes on investment and - most theoretical work on tax competition - has focussed on the impact of taxes at the margin [...]. Typically corporate income taxes raise the cost of capital - the required rate of return on an investment - and therefore act as a disincentive to invest. ${ }^{1}$ The two aspects of these reforms have offsetting effects on this disincentive: the lower tax rate typically increases the incentive to invest, while the lower allowance decreases 
it. The combined effect depends on the details of each reform" (Devereux, Griffith and Klemm, 2002).

Table 1 Statutory corporate tax rates (\%) for SMEs in the selected EU countries in the case of profit retention

\begin{tabular}{|l|c|c|c|c|c|c|}
\hline & Austria & Finland & France & Germany & Ireland & UK \\
\hline 1980 & 55 & 43 & 50 & 56 & 45 & $40(52)$ \\
1981 & 55 & 43 & 50 & 56 & 45 & $40(52)$ \\
1982 & 55 & 43 & 50 & 56 & 45 & $40(52)$ \\
1983 & 55 & 43 & 50 & 56 & 50 & $38(50)$ \\
1984 & 55 & 43 & 50 & 56 & 50 & $30(45)$ \\
1985 & 55 & 43 & 45 & 56 & 50 & $30(40)$ \\
1986 & 55 & 33 & 45 & 56 & 50 & $29(35)$ \\
1987 & 55 & 33 & 39 & 56 & 50 & $27(35)$ \\
1988 & 55 & 33 & 39 & 56 & 50 & $25(35)$ \\
1989 & 30 & 33 & 37 & 50 & 47 & $25(35)$ \\
1990 & 30 & 25 & 34 & 50 & 43 & $25(34)$ \\
1991 & 30 & 23 & 34 & 50 & 43 & $25(34)$ \\
1992 & 30 & 19 & 33.33 & 50 & 40 & $25(33)$ \\
1993 & 30 & 25 & 33.33 & 45 & 40 & $25(33)$ \\
1994 & 34 & 25 & 33.33 & 45 & 40 & $25(33)$ \\
1995 & 34 & 25 & 33.33 & 45 & 38 & $24(33)$ \\
1996 & 34 & 28 & 33.33 & 45 & 38 & $23(33)$ \\
1997 & 34 & 28 & 33.33 & 45 & 36 & $21(33)$ \\
1998 & 34 & 28 & 33.33 & 45 & 32 & $20(31)$ \\
1999 & 34 & 28 & 33.33 & 40 & 28 & $20(30)$ \\
2000 & 34 & 29 & 33.33 & 40 & $12,5(25)$ & $20(30)$ \\
2001 & 34 & 29 & 33.33 & 25 & $12.5(20)$ & $20(30)$ \\
2002 & 34 & 29 & 33.33 & 25 & $12.5(16)$ & $19(30)$ \\
2003 & 34 & 29 & 33.33 & 25 & 12.5 & $19(30)$ \\
\hline
\end{tabular}

Note: The rates shown in parentheses are standard statutory tax rates existing together with SME-specific corporate tax rates.

Source: Chen, Lee and Mintz (2002), Taxation, SMEs and Entrepreneuship, OECD, Paris; Devereux, Griffith and Klemm (2004), Why Has the UK Corporation Tax Raised So Much Revenue?, Fiscal Studies 25, 367-388; Office of Tax Policy Research (University of Michigan), World Tax Database; KPMG Corporate Tax Rate Survey (Various Years); Ifo Institute for Economic Research.

1 The principal idea of the user cost of capital approach is that a firm will invest until the point at which the marginal product of capital is equal to the cost of capital - so that, at the margin, the project just breaks even. As investment increases, the marginal product declines, resulting in a unique profitmaximising investment level (Hall and Jorgenson, 1967; Auerbach, 1983; King and Fullerton, 1984; Sinn, 1987; Devereux and Griffith, 2003; Gordon, Kalambokidis and Slemrod, 2004; Razin, Sadka and Nam, 2005). 
Table 2 Most popular generous tax depreciation rules for SMEs' equipment investment in selected EU countries when normal tax life $=10$ years

\begin{tabular}{|c|c|c|c|c|c|c|}
\hline & Austria & Finland & France & Germany & Ireland & UK \\
\hline 1980 & ita $20 \%+$ sld $10 \%$ & $\operatorname{gdd} 30 \%$ & $\operatorname{gdd} 25 \%$ & $\operatorname{gdd} 25 \%$ & $\mathrm{fd} 100 \%$ & fd $100 \%$ \\
\hline 1981 & ita $20 \%+$ sld $10 \%$ & $\operatorname{gdd} 30 \%$ & $\operatorname{gdd} 25 \%$ & $\operatorname{gdd} 30 \%$ & $\mathrm{fd} 100 \%$ & $\mathrm{fd} 100 \%$ \\
\hline 1982 & ita $20 \%+$ sld $10 \%$ & $\operatorname{gdd} 30 \%$ & $\operatorname{gdd} 25 \%$ & $\operatorname{gdd} 30 \%$ & $\mathrm{fd} 100 \%$ & $\mathrm{fd} 100 \%$ \\
\hline 1983 & ita $20 \%+$ sld $10 \%$ & $\operatorname{gdd} 30 \%$ & $\operatorname{gdd} 25 \%$ & $\operatorname{gdd} 30 \%$ & fd $100 \%$ & $\mathrm{fd} 100 \%$ \\
\hline 1984 & ita $20 \%+$ sld $10 \%$ & $\operatorname{gdd} 30 \%$ & $\operatorname{gdd} 25 \%$ & $\operatorname{gdd} 30 \%$ & $\mathrm{fd} 100 \%$ & $\mathrm{fd} 100 \%$ \\
\hline 1985 & ita $20 \%+$ sld $10 \%$ & $\operatorname{gdd} 30 \%$ & $\operatorname{gdd} 25 \%$ & $\operatorname{gdd} 30 \%$ & $\mathrm{fd} 100 \%$ & $\mathrm{fd} 100 \%$ \\
\hline 1986 & ita $20 \%+$ sld $10 \%$ & $\operatorname{gdd} 30 \%$ & $\operatorname{gdd} 25 \%$ & $\operatorname{gdd} 30 \%$ & $\mathrm{fd} 100 \%$ & $\mathrm{fd} 100 \%$ \\
\hline 1987 & ita $20 \%+$ sld $10 \%$ & $\operatorname{gdd} 30 \%$ & $\operatorname{gdd} 25 \%$ & $\operatorname{gdd} 30 \%$ & $\mathrm{fd} 100 \%$ & $\mathrm{fd} 100 \%$ \\
\hline 1988 & ita $20 \%+\operatorname{sld} 10 \%$ & $\operatorname{gdd} 30 \%$ & $\operatorname{gdd} 25 \%$ & $\operatorname{gdd} 30 \%$ & $\mathrm{fd} 100 \%$ & $\mathrm{fd} 100 \%$ \\
\hline 1989 & ita $20 \%+\operatorname{sld} 10 \%$ & $\operatorname{gdd} 30 \%$ & $\operatorname{gdd} 25 \%$ & $\operatorname{gdd} 30 \%$ & $\mathrm{fd} 100 \%$ & $\mathrm{fd} 100 \%$ \\
\hline 1990 & ita $20 \%+$ sld $10 \%$ & $\operatorname{gdd} 30 \%$ & $\operatorname{gdd} 25 \%$ & $\operatorname{gdd} 30 \%$ & $\mathrm{fd} 100 \%$ & $\mathrm{fd} 100 \%$ \\
\hline 1991 & ita $20 \%+$ sld $10 \%$ & $\operatorname{gdd} 30 \%$ & $\operatorname{gdd} 25 \%$ & $\operatorname{gdd} 30 \%$ & $\mathrm{fd} 100 \%$ & $\mathrm{fd} 100 \%$ \\
\hline 1992 & ita $20 \%+$ sld $10 \%$ & $\operatorname{gdd} 30 \%$ & $\operatorname{gdd} 25 \%$ & $\operatorname{gdd} 30 \%$ & sld15\%(6yrs)+10\%(1yr) & $\mathrm{fd} 100 \%$ \\
\hline 1993 & ita $20 \%+$ sld $10 \%$ & $\operatorname{gdd} 30 \%$ & $\operatorname{gdd} 25 \%$ & $\operatorname{gdd} 30 \%$ & sld $15 \%(6 y r s)+10 \%(1 y r)$ & $\mathrm{fd} 100 \%$ \\
\hline 1994 & ita $20 \%+$ sld $10 \%$ & $\operatorname{gdd} 30 \%$ & $\operatorname{gdd} 37.5 \%$ & $\operatorname{gdd} 30 \%$ & sld $15 \%(6 y r s)+10 \%(1 y r)$ & $\operatorname{gdd} 25 \%$ \\
\hline 1995 & ita $20 \%+$ sld $10 \%$ & $\operatorname{gdd} 30 \%$ & $\operatorname{gdd} 37.5 \%$ & $\operatorname{gdd} 30 \%$ & sld $15 \%(6 y r s)+10 \%(1 y r)$ & $\operatorname{gdd} 25 \%$ \\
\hline 1996 & ita $20 \%+$ sld $10 \%$ & $\operatorname{gdd} 30 \%$ & $\operatorname{gdd} 37.5 \%$ & $\operatorname{gdd} 30 \%$ & sld $15 \%(6 y r s)+10 \%(1 y r)$ & $\operatorname{gdd} 25 \%$ \\
\hline 1997 & ita $20 \%+$ sld $10 \%$ & $\operatorname{gdd} 30 \%$ & $\operatorname{gdd} 37.5 \%$ & $\operatorname{gdd} 30 \%$ & sld $15 \%(6 y r s)+10 \%(1 y r)$ & $\operatorname{gdd} 25 \%$ \\
\hline 1998 & ita $20 \%+$ sld $10 \%$ & $\operatorname{gdd} 30 \%$ & $\operatorname{gdd} 37.5 \%$ & $\operatorname{gdd} 30 \%$ & sld $15 \%(6 y r s)+10 \%(1 y r)$ & $\operatorname{ad} 30 \%+\operatorname{sld} 10 \%(7 \mathrm{yr})(\operatorname{gdd} 25 \%)$ \\
\hline 1999 & ita $9 \%+$ sld $10 \%$ & $\operatorname{gdd} 25 \%$ & $\operatorname{gdd} 37.5 \%$ & $\operatorname{gdd} 30 \%$ & sld $15 \%(6 y r s)+10 \%(1 y r)$ & $\operatorname{ad} 30 \%+\operatorname{sld} 10 \%(7 y r)(\operatorname{gdd} 25 \%)$ \\
\hline 2000 & ita $9 \%+$ sld $10 \%$ & $\operatorname{gdd} 25 \%$ & $\operatorname{gdd} 37.5 \%$ & $\operatorname{gdd} 30 \%$ & sld $15 \%(6 y r s)+10 \%(1 y r)$ & $\operatorname{ad} 30 \%+\operatorname{sld} 10 \%(7 \mathrm{yr})(\operatorname{gdd} 25 \%)$ \\
\hline 2001 & ita $9 \%+$ sld $10 \%$ & $\operatorname{gdd} 25 \%$ & $\operatorname{gdd} 37.5 \%$ & sld $10 \%$ & sld $20 \%$ & $\operatorname{ad} 30 \%+\operatorname{sld} 10 \%(7 \mathrm{yr})(\operatorname{gdd} 25 \%)$ \\
\hline 2002 & ita $9 \%+$ sld $10 \%$ & $\operatorname{gdd} 25 \%$ & $\operatorname{gdd} 37.5 \%$ & $\operatorname{sld} 10 \%$ & $\operatorname{sld} 20 \%$ & $\operatorname{ad} 30 \%+\operatorname{sld} 10 \%(7 \mathrm{yr})(\operatorname{gdd} 25 \%)$ \\
\hline 2003 & ita9\%+sld $10 \%$ & $\operatorname{gdd} 25 \%$ & $\operatorname{gdd} 37.5 \%$ & sld $10 \%$ & $\operatorname{sld} 20 \%$ & $\operatorname{ad} 30 \%+\operatorname{sld} 10 \%(7 \mathrm{yr})(\operatorname{gdd} 25 \%)$ \\
\hline
\end{tabular}

Note: ita $=$ investment tax allowance, sld $=$ straight-line depreciation, $g d d=$ geometric-degressive depreciation and fd $=$ free depreciation, ad $=$ accelerated depreciation. The depreciation methods and rates shown in parentheses are standard depreciation rules applicable for the investment in equipment.

Source: Chen, Lee and Mintz (2002), Taxation, SMEs and Entrepreneuship, OECD, Paris; Ifo Institute for Economic Research. 
A similar examination can also be carried out based on the present value model (Atkinson and Stiglitz, 1980; Nam and Radulescu, 2005). In other words this study argues that discrete investment choices of profit-maximising SMEs are dependent on the post-tax net present value. Without taxation, the net present value (NPV) is equal to the present value of future gross return, discounted at an appropriate interest rate less investment cost. After the introduction of tax on corporate income, the present value of the asset generated from an investment amounts to the sum of present value of net return (gross return less taxes) and tax savings led by an incentive depreciation provision. An investment project is considered to be profitable when the NPV is positive. A superior feature of such a model is that one can adequately consider different accounting methods of tax depreciation when inflation prevails.

Ceteris paribus two tax determinants (corporate tax rate and depreciation rule) vary in the model simulation, while other relevant parameters such as interest rate, economic depreciation, inflation rate, etc. are assumed to remain unchanged. Furthermore, it is a general belief that SMEs have limited access to capital markets, both nationally and internationally, in part because of the perception of higher risk, informational barriers and the involvement in smaller projects, etc. As a result, SMEs have quite often been unable to obtain long-term finance in the form of term debt and equity, and a larger part of their investments have traditionally been self-financed. ${ }^{2}$

Only in an exceptional case when tax depreciation corresponds to Samuelson's true economic depreciation and its calculation is based on current replacement cost of capital is the tax neutrality guaranteed. In spite of the fact that the inflation rate has been gradually decreased in Europe the low rate still appears to matter for the calculation of the tax base and SMEs' investment decisions. The changes in incentive effects of corporate tax policy measures in an inflationary economy can ideally be reflected in an international comparison when the country rankings are constructed according to the calculated nominal NPV. The study investigates the changes of tax burden on capital caused by the corporate tax reform in selected EU nations since the beginning of 1980s.

\section{Nominal Net Present Value Model}

The generosity of different types of tax concessions in combination with corporate tax rates can be measured on the basis of a net present value model. Under the assumptions

2 In most OECD countries the corporate tax system encourages debt financing and discriminates against SMEs, since corporate interest payments are tax deductible. Such a type of tax non-neutrality between the financing methods favours large firms, which have easier access to bank loans (Chen, Lee and Mintz, 2002, p. 15). 
that (i) an equity-financed investment generates an infinite stream of future gross return and (ii) this return exponentially declines at a given rate $\alpha(0<\alpha<1)$, Samuelson (1964) demonstrated in his fundamental theorem of tax-rate invariance that corporate income taxation does not affect firms' investment decisions at all, when true economic depreciation (TED) - the negative change in value of the asset in the course of time - is deducted from an expected gross stream of return when calculating tax profits. And the TED rate is the same rate at which the gross return declines in the course of time: i.e. the TED rate $=\alpha$ (Atkinson and Stiglitz, 1980; Sinn, 1987; Alvarez, Kanniainen and Södersten, 2000; Nam and Radulescu, 2005).

In an economy with the constant inflation rate $\pi$ but without taxation, an equity-financed investment of a profit-maximising SME is on the margin of acceptance at the year of investment, when

$$
\mathrm{C}=\mathrm{PV}_{0}=\int_{0}^{\infty} \mathrm{A}_{0} \mathrm{e}^{-(\alpha-\pi+\mu) \mathrm{u}} \mathrm{du}=\frac{\mathrm{A}_{0}}{\alpha+\mathrm{r}}
$$

where $\mathrm{A}_{0} \mathrm{e}^{-(\alpha-\pi+\mu) \mathrm{u}}$ means nominal gross return at year $\mathrm{u}$ generated by an investment costing $\mathrm{C}$ at time 0 , which is discounted by the nominal interest rate $\mu=\mathrm{r}+\pi(0<\mathrm{r}<1)$. In this case, the sum of annual gross return exponentially decreases at $\alpha$ but increases at $\pi$ in the course of time. In such an equilibrium technically expressed in equation (1), inflation does not play any role for the investment decision and NPV $\left(=\mathrm{PV}_{0}-\mathrm{C}\right)$ amounts to zero. Such a steady-state condition usually plays the basis role for the further analyses on corporate tax systems.

In the case of adopting geometric-degressive depreciation and if its calculation is made based on the current cost accounting system, ${ }^{3}$ nominal present value can be expressed as

$$
\begin{aligned}
\mathrm{nPV}(\mathrm{t})_{0}{ }^{\text {gdd,cur }} & =(1-\mathrm{t}) \int_{0}^{\infty} \mathrm{A}_{0} \mathrm{e}^{-\{\alpha-\pi+\mu(1-\mathrm{t})\} \mathrm{u}} \mathrm{du}+\mathrm{tC} \int_{0}^{\infty} \delta \mathrm{e}^{-\{(\delta-\pi)+\mu(1-\mathrm{t})\} \mathrm{u}} \mathrm{du} \\
& =\mathrm{PV} \mathrm{V}_{0}+\mathrm{tC}\left\{\frac{\delta-\pi}{\delta-\pi+\mu(1-\mathrm{t})}-\frac{\alpha-\pi}{\alpha-\pi+\mu(1-\mathrm{t})}\right\}
\end{aligned}
$$

3 If input prices change, it is necessary to recover the cost of replacing the services consumed in producing the goods or services for sale at their current prices. Hence, the current cost accounting is generally understood as accounting for the current replacement cost of non-monetary assets (see also Nam and Radulescu, 2004). 
where $\delta$ indicates the geometric-degressive depreciation rate and $\mathrm{Ce}^{-(\delta-\pi) \mathrm{u}}$ shows the (nominal) net book value of capital good in the period u. Therefore, with $\delta=\delta^{*}=\alpha$ $\mathrm{nPV}(\mathrm{t})^{*}{ }_{0}^{\text {gdd,cur }}=\mathrm{PV}_{0}=\mathrm{C}$ in equilibrium, the so-called tax neutrality is guaranteed ${ }^{4}$ and inflation does not disturb the investment decision at all.

When the historical accounting method ${ }^{5}$ is applied as the usual case in practice

$$
\begin{aligned}
\mathrm{nPV}(\mathrm{t})_{0} \mathrm{gdd}^{\mathrm{gis}} & =(1-\mathrm{t}) \int_{0}^{\infty} \mathrm{A}_{0} \mathrm{e}^{-\{\alpha-\pi+\mu(1-\mathrm{t})\} \mathrm{u}} \mathrm{du}+\mathrm{tC} \int_{0}^{\infty} \delta \mathrm{e}^{-\{\delta+\mu(1-\mathrm{t})\} \mathrm{u}} \mathrm{du} \\
& =\mathrm{PV}_{0}+\mathrm{tC}\left\{\frac{\delta}{\delta+\mu(1-\mathrm{t})}-\frac{\alpha-\pi}{\alpha-\pi+\mu(1-\mathrm{t})}\right\}
\end{aligned}
$$

where $\mathrm{Ce}^{-\delta \mathrm{u}}$ shows the net book value of capital good in the period $\mathrm{u}$ in this case.

When $\delta^{*}=\alpha$, a fictitious gain (FG) in nominal present value with geometric-degressive depreciation emerges through the adoption of historical accounting method since $\mathrm{nPV}(\mathrm{t})_{0}{ }^{\text {gdd*, his }}$ is larger than $\mathrm{nPV}(\mathrm{t})_{0}{ }^{\text {gdd*,cur }}$.

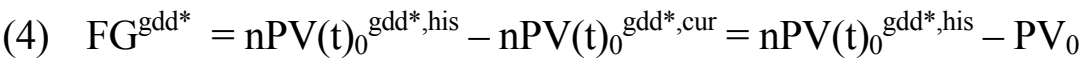

$$
=\mathrm{tC}\left\{\frac{\delta^{*}}{\delta^{*}+\mu(1-\mathrm{t})}-\frac{\delta^{*}-\pi}{\delta^{*}-\pi+\mu(1-\mathrm{t})}\right\} .
$$

In the case of employing the historical cost accounting method, the nominal present value of the asset with straight-line depreciation at time 0 is

$$
\mathrm{nPV}(\mathrm{t})_{0}{ }^{\text {sld,his }}=(1-\mathrm{t}) \int_{0}^{\infty} \mathrm{A}_{0} \mathrm{e}^{-\{\alpha-\pi+\mu(1-\mathrm{t})\} \mathrm{u}} \mathrm{du}+\mathrm{t} \int_{0}^{\Gamma}(\mathrm{C} / \Gamma) \mathrm{e}^{-\{\mu(1-\mathrm{t})\} \mathrm{u}} \mathrm{du}
$$

\footnotetext{
Comparably the condition $\delta=\alpha$ is also the compulsory prerequisite to obtain tax neutrality in the marginal approach (King and Fullerton, 1984; Sinn, 1987; Sørensen, 2004).

5 More precisely, under the historical cost accounting system the capital to be recovered before a profit is recognised as simply the amount of money originally invested in the firm. Historical profits are, therefore, the current period's revenue subtracted by the historical cost of inputs necessary to secure the current period's expenses. It has long been recognised that increases in input prices can cause historical cost accounting to seriously overstate a firm's ability to distribute its reported profits, continue producing the same physical volume of goods and services, and understate the firm's capital (see also Nam and Radulescu, 2004).
} 


$$
=\mathrm{PV}_{0}+\mathrm{tC}\left\{\frac{1-\mathrm{e}^{-\mu(1-\mathrm{t}) \Gamma}}{\mu(1-\mathrm{t}) \Gamma}-\frac{\alpha-\pi}{\alpha-\pi+\mu(1-\mathrm{t})}\right\}
$$

where $\Gamma$ indicates the normal tax life of a capital good. The true investment promotion (TIP) of corporate taxation system accompanied by straight-line depreciation takes place when $\mathrm{nPV}(\mathrm{t})_{0}{ }^{\text {sld,his }}-\mathrm{C}>\mathrm{FG}^{\mathrm{gdd}}$.

In the context of free depreciation the sum of $\mathrm{C}$ can be fully written off in the first year. When employing this depreciation method, the nominal present value of asset at year 0 is

$$
\begin{aligned}
\mathrm{nPV}(\mathrm{t})_{0}{ }^{\mathrm{fd}, \mathrm{his}} & =(1-\mathrm{t}) \int_{0}^{\infty} \mathrm{A}_{0} \mathrm{e}^{-\{\alpha-\pi+\mu(1-\mathrm{t})\} \mathrm{u}} \mathrm{du}+\int_{0}^{1} \mathrm{Ce}^{-\mu(1-\mathrm{t}) \mathrm{u}} \mathrm{du} \\
& =\mathrm{PV}_{0}+\mathrm{tC}\left\{\frac{1-\mathrm{e}^{-\mu(1-\mathrm{t})}}{\mu(1-\mathrm{t})}-\frac{\alpha-\pi}{\alpha-\pi+\mu(1-\mathrm{t})}\right\} .
\end{aligned}
$$

TIP of free depreciation takes place in spite of applying historical accounting method when nominal NPV with free depreciation $\left(=\mathrm{nPV}(\mathrm{t})_{0}{ }^{\text {fd,his }}-\mathrm{C}\right)$ is larger than $\mathrm{FG}^{\text {gdd* }}$.

Furthermore, a certain percentage share of $\mathrm{C}$ referred to as investment tax allowance can be deducted from gross profit in the first year when calculating the tax base. Investment tax allowance is commonly applied in combination with straight-line depreciation. As a consequence, this type of tax incentive provides possibilities of depreciating the value which is significantly higher than the original investment cost of a capital good.

With investment tax allowance, nominal present value of asset at year 0 is

$$
\begin{aligned}
\mathrm{nPV}(\mathrm{t})_{0}{ }^{\mathrm{ita}, \mathrm{his}} & =(1-\mathrm{t}) \int_{0}^{\infty} \mathrm{A}_{0} \mathrm{e}^{-\{\alpha-\pi+\mu(1-\mathrm{t})\} \mathrm{u}} \mathrm{du}+\int_{0}^{1}(\beta \mathrm{C}) \mathrm{e}^{-\mu(1-\mathrm{t}) \mathrm{u}} \mathrm{du}+\mathrm{t} \int_{0}^{\Gamma}(\mathrm{C} / \Gamma) \mathrm{e}^{-\mu(1-\mathrm{t}) \mathrm{u}} \mathrm{du} \\
& =\mathrm{PV}_{0}+\mathrm{tC}\left[\frac{\beta\left\{1-\mathrm{e}^{-\mu(1-\mathrm{t})}\right\}}{\mu(1-\mathrm{t})}+\frac{1-\mathrm{e}^{-\mu(1-\mathrm{t}) \Gamma}}{\mu(1-\mathrm{t}) \Gamma}-\frac{\alpha-\pi}{\alpha-\pi+\mu(1-\mathrm{t})}\right]
\end{aligned}
$$

where $\beta$ indicates the rate of investment tax allowance $(0<\beta<1)$. TIP is expected when $\mathrm{nPV}(\mathrm{t})_{0}{ }^{\text {ita,his }}-\mathrm{C}>\mathrm{FG}^{\text {gdd* }}$.

Accelerated depreciation is also combined with the straight-line depreciation method. Accelerated depreciation expense - as a certain percentage share $(\sigma)$ of $\mathrm{C}$ - is taxdeductible in the first year of a capital good's tax life $(0<\sigma<1)$. Consequently, the total 
depreciation expense in the first year amounts to $\sigma \mathrm{C}+\mathrm{C} / \Gamma$ and the total tax life of a capital good is reduced correspondingly from $\Gamma$ to $\Omega$, where $\Omega=(1-\sigma) \Gamma$. In the case of adopting the historical accounting method the nominal present value of the asset with accelerated depreciation at year 0 is

$$
\begin{aligned}
& \mathrm{nPV}(\mathrm{t})_{0}{ }^{\text {ad,his }}=(1-\mathrm{t}) \int_{0}^{\infty} \mathrm{A}_{0} \mathrm{e}^{-\{\alpha-\pi+\mu(1-\mathrm{t})\} \mathrm{u}} \mathrm{du}+\mathrm{t} \int_{0}^{1} \sigma \mathrm{Ce}^{-\mu(1-t) \mathrm{u}} \mathrm{du}+\mathrm{t} \int_{0}^{\Omega}(\mathrm{C} / \Gamma) \mathrm{e}^{-\mu(1-t) \mathrm{u}} \mathrm{du} \\
& =\mathrm{PV}_{0}+\mathrm{tC}\left[\frac{\sigma\left\{1-\mathrm{e}^{-\mu(1-\mathrm{t})}\right\}}{\mu(1-\mathrm{t})}+\frac{1-\mathrm{e}^{-\mu(1-\mathrm{t}) \Omega}}{\mu(1-\mathrm{t}) \Gamma}-\frac{\alpha-\pi}{\alpha-\pi+\mu(1-\mathrm{t})}\right]
\end{aligned}
$$

Analogously TIP with accelerated depreciation exists when $\mathrm{nPV}(\mathrm{t})_{0}{ }^{\text {ad,his }}-\mathrm{C}>\mathrm{FG}^{\text {gdd* }}$.

\section{Major Results of Model Simulation}

The study investigates the corporate tax reform and its effect on SME's nominal NPV in six selected EU nations - Austria, Finland, France, Germany, Ireland and the UK for the period of 1980-2003. Two tax policy measures - corporate tax rate and depreciation provision - change in the model simulation, while other relevant parameters like interest rate, economic depreciation, inflation rate, etc. are given. For the calculation statutory corporate tax rates and depreciation rules are applied for the individual years, which are demonstrated in Tables 1 and 2. Further assumptions made in the simulations are $\mathrm{A}_{0}=100 ; \mathrm{r}=4 \%, \alpha=\delta^{*}=20 \%, \mathrm{C}=\mathrm{PV}_{0}=416.7, \Gamma=10$ years for equipment whereas $\pi$ varies from $2 \%$ to $4 \%$ and $6 \%$.

As had been anticipated a priori, the development of $\mathrm{FG}^{\text {gdd* }}$ values were positively correlated to $t$ and $\pi$ in the observed period (Tables 3 to 5). In general a constant increase of $\pi$ led to a progressively rising $\mathrm{FG}^{\text {gdd*, }}$, although $\mathrm{t}$ remained unchanged. Moreover, the extent of $\mathrm{FG}^{\text {gdd* }}$ change (i.e. increase and decrease) caused by the variation of $\mathrm{t}$ generally became more apparent, when the assumed $\pi$ got higher. As shown in terms of mean values in Tables 3 to 5 , the corporate tax reduction introduced in the selected countries also contributed to the gradual decrease of $\mathrm{FG}^{\text {gdd* }}$, which is, however, accompanied by the slightly increasing standard deviation values in the course of time. 
Table 3 Effects of corporate tax rate change on SME's fictitious gain (FG gdd*) when $\pi=2 \%$ and $\delta^{*}=\alpha$ : investment in equipment

\begin{tabular}{|l|l|l|l|l|l|l|l|c|}
\hline & Austria & Finland & France & Germany & Ireland & UK & Mean & $\begin{array}{c}\text { Standard } \\
\text { deviation }\end{array}$ \\
\hline 1980 & 2.63 & 2.44 & 2.59 & 2.64 & 2.49 & 2.35 & 2.52 & 0.11 \\
1981 & 2.63 & 2.44 & 2.59 & 2.64 & 2.49 & 2.35 & 2.52 & 0.11 \\
1982 & 2.63 & 2.44 & 2.59 & 2.64 & 2.49 & 2.35 & 2.52 & 0.11 \\
1983 & 2.63 & 2.44 & 2.59 & 2.64 & 2.59 & 2.29 & 2.53 & 0.13 \\
1984 & 2.63 & 2.44 & 2.59 & 2.64 & 2.59 & 1.95 & 2.47 & 0.24 \\
1985 & 2.63 & 2.44 & 2.49 & 2.64 & 2.59 & 1.95 & 2.46 & 0.24 \\
1986 & 2.63 & 2.10 & 2.49 & 2.64 & 2.59 & 1.91 & 2.39 & 0.28 \\
1987 & 2.63 & 2.10 & 2.32 & 2.64 & 2.59 & 1.81 & 2.33 & 0.30 \\
1988 & 2.63 & 2.10 & 2.32 & 2.64 & 2.59 & 1.70 & 2.32 & 0.33 \\
1989 & 1.95 & 2.10 & 2.25 & 2.59 & 2.54 & 1.70 & 2.19 & 0.31 \\
1990 & 1.95 & 1.70 & 2.13 & 2.59 & 2.44 & 1.70 & 2.09 & 0.34 \\
1991 & 1.95 & 1.59 & 2.13 & 2.59 & 2.44 & 1.70 & 2.07 & 0.36 \\
1992 & 1.95 & 1.35 & 2.10 & 2.59 & 2.35 & 1.70 & 2.01 & 0.41 \\
1993 & 1.95 & 1.70 & 2.10 & 2.49 & 2.35 & 1.70 & 2.05 & 0.30 \\
1994 & 2.13 & 1.70 & 2.10 & 2.49 & 2.35 & 1.65 & 2.07 & 0.31 \\
1995 & 2.13 & 1.70 & 2.10 & 2.49 & 2.29 & 1.59 & 2.05 & 0.31 \\
1996 & 2.13 & 1.86 & 2.10 & 2.49 & 2.29 & 1.47 & 2.06 & 0.32 \\
1997 & 2.13 & 1.86 & 2.10 & 2.49 & 2.21 & 1.41 & 2.03 & 0.33 \\
1998 & 2.13 & 1.86 & 2.10 & 2.49 & 2.05 & 1.41 & 2.01 & 0.33 \\
1999 & 2.13 & 1.86 & 2.10 & 2.35 & 1.86 & 1.41 & 1.95 & 0.30 \\
2000 & 2.13 & 1.91 & 2.10 & 2.35 & 0.93 & 1.41 & 1.81 & 0.49 \\
2001 & 2.13 & 1.91 & 2.10 & 1.70 & 0.93 & 1.41 & 1.70 & 0.42 \\
2002 & 2.13 & 1.91 & 2.10 & 1.70 & 0.93 & 1.35 & 1.69 & 0.43 \\
2003 & 2.13 & 1.91 & 2.10 & 1.70 & 0.93 & 1.35 & 1.69 & 0.43 \\
\hline
\end{tabular}

Common assumptions: $\mathrm{A}_{0}=100, \mathrm{r}=4 \%, \alpha=\delta^{*}=20 \%$ and $\mathrm{C}=\mathrm{PV}_{0}=416.7$.

Source: Table 1 and own calculations. 
Table 4 Effects of corporate tax rate change on SME's fictitious gain (FGgdd*) when $\pi=4 \%$ and $\delta^{*}=\alpha$ : investment in equipment

\begin{tabular}{|l|l|l|l|l|l|l|l|c|}
\hline & Austria & Finland & France & Germany & Ireland & UK & Mean & $\begin{array}{c}\text { Standard } \\
\text { deviation }\end{array}$ \\
\hline 1980 & 7.13 & 6.47 & 6.94 & 7.16 & 6.63 & 6.20 & 6.76 & 0.35 \\
1981 & 7.13 & 6.47 & 6.94 & 7.16 & 6.63 & 6.20 & 6.76 & 0.35 \\
1982 & 7.13 & 6.47 & 6.94 & 7.16 & 6.63 & 6.20 & 6.76 & 0.35 \\
1983 & 7.13 & 6.47 & 6.94 & 7.16 & 6.94 & 6.00 & 6.77 & 0.41 \\
1984 & 7.13 & 6.47 & 6.94 & 7.16 & 6.94 & 5.06 & 6.62 & 0.73 \\
1985 & 7.13 & 6.47 & 6.63 & 7.16 & 6.94 & 5.06 & 6.57 & 0.72 \\
1986 & 7.13 & 5.44 & 6.63 & 7.16 & 6.94 & 4.93 & 6.37 & 0.87 \\
1987 & 7.13 & 5.44 & 6.11 & 7.16 & 6.94 & 4.66 & 6.24 & 0.94 \\
1988 & 7.13 & 5.44 & 6.11 & 7.16 & 6.94 & 4.37 & 6.19 & 1.02 \\
1989 & 5.06 & 5.44 & 5.90 & 6.94 & 6.77 & 4.37 & 5.75 & 0.91 \\
1990 & 5.06 & 4.37 & 5.56 & 6.94 & 6.47 & 4.37 & 5.46 & 0.98 \\
1991 & 5.06 & 4.07 & 5.56 & 6.94 & 6.47 & 4.37 & 5.41 & 1.04 \\
1992 & 5.06 & 3.44 & 5.48 & 6.94 & 6.20 & 4.37 & 5.25 & 1.15 \\
1993 & 5.06 & 4.37 & 5.48 & 6.63 & 6.20 & 4.37 & 5.35 & 0.85 \\
1994 & 5.56 & 4.37 & 5.48 & 6.63 & 6.20 & 4.37 & 5.44 & 0.85 \\
1995 & 5.56 & 4.37 & 5.48 & 6.63 & 6.00 & 4.22 & 5.38 & 0.85 \\
1996 & 5.56 & 4.80 & 5.48 & 6.63 & 6.00 & 4.07 & 5.42 & 0.82 \\
1997 & 5.56 & 4.80 & 5.48 & 6.63 & 5.79 & 3.77 & 5.34 & 0.88 \\
1998 & 5.56 & 4.80 & 5.48 & 6.63 & 5.32 & 3.61 & 5.23 & 0.91 \\
1999 & 5.56 & 4.80 & 5.48 & 6.20 & 4.80 & 3.61 & 5.08 & 0.81 \\
2000 & 5.56 & 4.93 & 5.48 & 6.20 & 2.35 & 3.61 & 4.69 & 1.31 \\
2001 & 5.56 & 4.93 & 5.48 & 4.37 & 2.35 & 3.61 & 4.38 & 1.13 \\
2002 & 5.56 & 4.93 & 5.48 & 4.37 & 2.35 & 3.45 & 4.36 & 1.15 \\
2003 & 5.56 & 4.93 & 5.48 & 4.37 & 2.35 & 3.45 & 4.36 & 1.15 \\
\hline
\end{tabular}

Common assumptions: $\mathrm{A}_{0}=100, \mathrm{r}=4 \%, \alpha=\delta^{*}=20 \%$ and $\mathrm{C}=\mathrm{PV}_{0}=416.7$.

Source: Table 1 and own calculations. 
Table 5 Effects of corporate tax rate change on SME's fictitious gain (FGgdd*) when $\pi=6 \%$ and $\delta^{*}=\alpha$ : investment in equipment

\begin{tabular}{|l|c|c|c|c|c|c|c|c|}
\hline & Austria & Finland & France & Germany & Ireland & UK & Mean & $\begin{array}{c}\text { Standard } \\
\text { deviation }\end{array}$ \\
\hline 1980 & 13.65 & 12.10 & 13.16 & 13.72 & 12.44 & 11.54 & 12.77 & 0.81 \\
1981 & 13.65 & 12.10 & 13.16 & 13.72 & 12.44 & 11.54 & 12.77 & 0.81 \\
1982 & 13.65 & 12.10 & 13.16 & 13.72 & 12.44 & 11.54 & 12.77 & 0.81 \\
1983 & 13.65 & 12.10 & 13.16 & 13.72 & 13.16 & 11.13 & 12.82 & 0.92 \\
1984 & 13.65 & 12.10 & 13.16 & 13.72 & 13.16 & 9.26 & 12.51 & 1.55 \\
1985 & 13.65 & 12.10 & 12.44 & 13.72 & 13.16 & 9.26 & 12.39 & 1.52 \\
1986 & 13.65 & 10.00 & 12.44 & 13.72 & 13.16 & 9.00 & 12.00 & 1.84 \\
1987 & 13.65 & 10.00 & 11.34 & 13.72 & 13.16 & 8.47 & 11.72 & 1.98 \\
1988 & 13.65 & 10.00 & 11.34 & 13.72 & 13.16 & 7.93 & 11.63 & 2.13 \\
1989 & 9.26 & 10.00 & 10.92 & 13.16 & 12.75 & 7.93 & 10.67 & 1.85 \\
1990 & 9.26 & 7.93 & 10.24 & 13.16 & 12.10 & 7.93 & 10.10 & 1.98 \\
1991 & 9.26 & 7.37 & 10.24 & 13.16 & 12.10 & 7.93 & 10.01 & 2.09 \\
1992 & 9.26 & 6.20 & 10.08 & 13.16 & 11.54 & 7.93 & 9.70 & 2.28 \\
1993 & 9.26 & 7.93 & 10.08 & 12.44 & 11.54 & 7.93 & 9.86 & 1.70 \\
1994 & 10.24 & 7.93 & 10.08 & 12.44 & 11.54 & 7.93 & 10.03 & 1.68 \\
1995 & 10.24 & 7.93 & 10.08 & 12.44 & 11.13 & 7.65 & 9.91 & 1.69 \\
1996 & 10.24 & 8.74 & 10.08 & 12.44 & 11.13 & 7.37 & 10.00 & 1.62 \\
1997 & 10.24 & 8.74 & 10.08 & 12.44 & 10.70 & 6.79 & 9.83 & 1.74 \\
1998 & 10.24 & 8.74 & 10.08 & 12.44 & 9.76 & 6.49 & 9.63 & 1.79 \\
1999 & 10.24 & 8.74 & 10.08 & 11.54 & 8.74 & 6.49 & 9.31 & 1.58 \\
2000 & 10.24 & 9.00 & 10.08 & 11.54 & 4.18 & 6.49 & 8.59 & 2.51 \\
2001 & 10.24 & 9.00 & 10.08 & 7.93 & 4.18 & 6.49 & 7.99 & 2.13 \\
2002 & 10.24 & 9.00 & 10.08 & 7.93 & 4.18 & 6.20 & 7.94 & 2.17 \\
2003 & 10.24 & 9.00 & 10.08 & 7.93 & 4.18 & 6.20 & 7.94 & 2.17 \\
\hline
\end{tabular}

Common assumptions: $\mathrm{A}_{0}=100, \mathrm{r}=4 \%, \alpha=\delta^{*}=20 \%$ and $\mathrm{C}=\mathrm{PV}_{0}=416.7$.

Source: Table 1 and own calculations.

In most of the investigated countries (except Germany and France) the investment promotion effect of corporate tax system measured in terms of TIP (= NPV with tax depreciation rule subtracted by $\mathrm{FG}^{\text {gdd* }}$ ) continued to decline. Regardless of assumed $\pi$, this fact is well illustrated by the gradually decreasing mean and standard deviation of TIP values in the course of time (Tables 6-8). Moreover the difference between the highest and the lowest mean value and the corresponding difference of standard deviation grew with $\pi$, although their growth appears to be rather moderate. 
Table 6 True investment promotion (TIP) effect for SMEs in the selected EU countries with $\pi=2 \%$ : investment in equipment

\begin{tabular}{|c|c|c|c|c|c|c|c|c|}
\hline & Austria & Finland & France & Germany & Ireland & UK & Mean & $\begin{array}{l}\text { Standard } \\
\text { deviation }\end{array}$ \\
\hline 1980 & $44.15(1)$ & $7.83(4)$ & $5.00(5)$ & $4.92(6)$ & $23.51(2)$ & $22.46(3)$ & 17.98 & 14.01 \\
\hline 1981 & $44.15(1)$ & $7.83(5)$ & $5.00(6)$ & $8.33(4)$ & $23.51(2)$ & $22.46(3)$ & 19.55 & 13.53 \\
\hline 1982 & 44.15 (1) & $7.83(5)$ & $5.00(6)$ & 8.33 (4) & $23.51(2)$ & $22.46(3)$ & 18.55 & 13.53 \\
\hline 1983 & $44.15(1)$ & $7.83(5)$ & $5.00(6)$ & 8.33 (4) & $24.10(2)$ & 21.92 (3) & 18.56 & 13.54 \\
\hline 1984 & 44.15 (1) & $7.83(5)$ & $5.00(6)$ & $8.33(4)$ & $24.10(2)$ & $19.11(3)$ & 18.09 & 13.47 \\
\hline 1985 & $44.15(1)$ & $7.83(5)$ & $4.70(6)$ & $8.33(4)$ & $24.10(2)$ & $19.11(3)$ & 18.04 & 13.52 \\
\hline 1986 & $44.15(1)$ & 6.75 (5) & $4.70(6)$ & $8.33(4)$ & $24.10(2)$ & 18.67 (3) & 17.78 & 13.65 \\
\hline 1987 & $44.15(1)$ & $6.75(5)$ & $4.39(6)$ & $8.33(4)$ & $24.10(2)$ & $17.78(3)$ & 17.58 & 13.70 \\
\hline 1988 & $44.15(1)$ & $6.75(5)$ & 4.39 (6) & 8.33 (4) & $24.10(2)$ & $16.82(3)$ & 17.42 & 13.70 \\
\hline 1989 & $23.25(2)$ & $6.75(5)$ & $4.26(6)$ & 8.23 (4) & 23.73 (1) & $16.82(3)$ & 13.84 & 7.84 \\
\hline 1990 & $23.25(1)$ & 5.55 (5) & $4.04(6)$ & $8.23(4)$ & $23.14(2)$ & $16.82(3)$ & 13.51 & 7.95 \\
\hline 1991 & $23.25(1)$ & 5.19 (5) & $4.04(6)$ & $8.23(4)$ & $23.14(2)$ & $16.82(3)$ & 13.45 & 8.01 \\
\hline 1992 & $23.25(1)$ & $4.44(5)$ & $4.00(6)$ & $8.23(3)$ & $6.08(4)$ & $16.82(2)$ & 10.47 & 7.14 \\
\hline 1993 & $23.25(1)$ & $5.55(5)$ & $4.00(6)$ & 7.98 (3) & $6.08(4)$ & $16.82(2)$ & 10.61 & 7.01 \\
\hline 1994 & $26.51(1)$ & $5.55(5)$ & $9.76(2)$ & $7.98(3)$ & $6.08(4)$ & $3.29(6)$ & 9.86 & 7.71 \\
\hline 1995 & $26.51(1)$ & $5.55(5)$ & $9.76(2)$ & 7.98 (3) & 5.89 (4) & $3.20(6)$ & 9.82 & 7.74 \\
\hline 1996 & $26.51(1)$ & $6.03(4)$ & $9.76(2)$ & 7.98 (3) & $5.89(5)$ & $3.16(6)$ & 9.89 & 7.70 \\
\hline 1997 & $26.51(1)$ & $6.03(4)$ & $9.76(2)$ & 7.98 (3) & 5.69 (5) & $2.88(6)$ & 9.81 & 7.76 \\
\hline 1998 & $26.51(1)$ & $6.03(5)$ & $9.76(2)$ & $7.98(3)$ & $5.24(6)$ & $6.75(4)$ & 10.83 & 7.36 \\
\hline 1999 & $11.23(1)$ & $3.53(6)$ & $9.76(2)$ & 7.57 (3) & $4.73(4)$ & $6.75(4)$ & 7.26 & 2.67 \\
\hline 2000 & $11.23(1)$ & 3.62 (5) & $9.76(2)$ & 7.57 (3) & $2.33(6)$ & $6.75(4)$ & 6.88 & 3.14 \\
\hline 2001 & $11.23(1)$ & $3.62(5)$ & $9.76(2)$ & $-1.15(6)$ & $4.56(4)$ & $6.75(3)$ & 5.80 & 4.10 \\
\hline 2002 & $11.23(1)$ & $3.62(5)$ & $9.76(2)$ & $-1.15(6)$ & $4.56(4)$ & 6.47 (3) & 5.75 & 4.09 \\
\hline 2003 & $11.23(1)$ & $3.62(5)$ & $9.76(2)$ & $-1.15(6)$ & $4.56(4)$ & $6.47(3)$ & 5.75 & 4.09 \\
\hline
\end{tabular}

Common assumptions: $\mathrm{A}_{0}=100, \mathrm{r}=4 \%, \alpha=\delta^{*}=20 \%, \mathrm{C}=\mathrm{PV}_{0}=416.7$ and $\Gamma=10$ years.

Note: The bold numbers indicate the ITP values (= nominal net present values minus FG $^{\text {gdd* }}$ ) and the ranks led by corporate tax reforms. The ranks are shown in parentheses.

Source: Tables 1-3; own calculations. 
Table 7 True investment promotion (TIP) effect for SMEs in the selected EU countries with $\pi=4 \%$ : investment in equipment

\begin{tabular}{|c|c|c|c|c|c|c|c|c|}
\hline & Austria & Finland & France & Germany & Ireland & UK & Mean & $\begin{array}{c}\text { Standard } \\
\text { deviation }\end{array}$ \\
\hline 1980 & $43.27(1)$ & $9.63(4)$ & $5.99(6)$ & $6.12(5)$ & $29.75(2)$ & $28.32(3)$ & 20.51 & 14.15 \\
1981 & $43.27(1)$ & $9.63(5)$ & $5.99(6)$ & $\mathbf{1 0 . 4 1 ( 4 )}$ & $29.75(2)$ & $28.32(3)$ & 21.23 & 13.49 \\
1982 & $43.27(1)$ & $9.63(5)$ & $5.99(6)$ & $10.41(4)$ & $29.75(2)$ & $28.32(3)$ & 21.23 & 13.49 \\
1983 & $43.27(1)$ & $9.63(5)$ & $5.99(6)$ & $10.41(4)$ & $\mathbf{3 0 . 6 2 ( 2 )}$ & $\mathbf{2 7 . 6 1 ( 3 )}$ & 21.26 & 13.53 \\
1984 & $43.27(1)$ & $9.63(5)$ & $5.99(6)$ & $10.41(4)$ & $30.62(2)$ & $\mathbf{2 3 . 9 1 ( 3 )}$ & 20.64 & 13.31 \\
1985 & $43.27(1)$ & $9.63(5)$ & $\mathbf{5 . 7 5 ( 6 )}$ & $10.41(4)$ & $30.62(2)$ & $23.91(3)$ & 20.60 & 13.35 \\
1986 & $43.27(1)$ & $\mathbf{8 . 2 2 ( 5 )}$ & $5.75(6)$ & $10.41(4)$ & $30.62(2)$ & $\mathbf{2 3 . 3 6 ( 3 )}$ & 20.27 & 13.53 \\
1987 & $43.27(1)$ & $8.22(5)$ & $\mathbf{5 . 3 3 ( 6 )}$ & $10.41(4)$ & $30.62(2)$ & $\mathbf{2 2 . 2 0 ( 3 )}$ & 20.01 & 13.57 \\
1988 & $43.27(1)$ & $8.22(5)$ & $5.33(6)$ & $10.41(4)$ & $30.62(2)$ & $\mathbf{2 0 . 9 8 ( 3 )}$ & 19.81 & 13.55 \\
1989 & $\mathbf{2 2 . 3 7 ( 3 )}$ & $8.22(5)$ & $\mathbf{5 . 1 6 ( 6 )}$ & $\mathbf{1 0 . 2 2 ( 4 )}$ & $\mathbf{3 0 . 1 6 ( 1 )}$ & $20.98(3)$ & 16.19 & 8.92 \\
1990 & $22.37(3)$ & $\mathbf{6 . 6 8 ( 5 )}$ & $\mathbf{4 . 8 9 ( 6 )}$ & $10.22(4)$ & $\mathbf{2 9 . 2 4 ( 1 )}$ & $20.98(3)$ & 15.73 & 8.98 \\
1991 & $22.37(3)$ & $\mathbf{6 . 2 4 ( 5 )}$ & $4.89(6)$ & $10.22(4)$ & $29.24(1)$ & $20.98(3)$ & 15.66 & 9.06 \\
1992 & $22.37(1)$ & $\mathbf{5 . 3 2 ( 5 )}$ & $\mathbf{4 . 8 2}(\mathbf{6})$ & $10.22(3)$ & $\mathbf{7 . 1 5 ( 4 )}$ & $20.98(2)$ & 11.81 & 7.20 \\
1993 & $22.37(1)$ & $\mathbf{6 . 6 8 ( 5 )}$ & $4.82(6)$ & $\mathbf{9 . 8 3 ( 3 )}$ & $7.15(4)$ & $20.98(2)$ & 11.97 & 7.03 \\
1994 & $\mathbf{2 5 . 5 9 ( 1 )}$ & $6.68(5)$ & $\mathbf{1 1 . 9 5 ( 2 )}$ & $9.83(3)$ & $7.15(4)$ & $\mathbf{3 . 8 7}(\mathbf{6 )}$ & 10.85 & 7.06 \\
1995 & $25.59(1)$ & $6.68(5)$ & $11.95(2)$ & $9.83(3)$ & $\mathbf{6 . 9 0 ( 4 )}$ & $\mathbf{3 . 7 5 ( 6 )}$ & 10.78 & 7.11 \\
1996 & $25.59(1)$ & $\mathbf{7 . 2 9 ( 4 )}$ & $11.95(2)$ & $9.83(3)$ & $6.90(5)$ & $\mathbf{3 . 6 2 ( 6 )}$ & 10.86 & 7.07 \\
1997 & $25.59(1)$ & $7.29(4)$ & $11.95(2)$ & $9.83(3)$ & $\mathbf{6 . 6 4 ( 5 )}$ & $\mathbf{3 . 3 5 ( 6 )}$ & 10.78 & 7.14 \\
1998 & $25.59(1)$ & $7.29(5)$ & $11.95(2)$ & $9.83(3)$ & $\mathbf{6 . 0 6 ( 6 )}$ & $\mathbf{8 . 1 0 ( 4 )}$ & 11.47 & 6.59 \\
1999 & $\mathbf{1 0 . 4 1 ( 2 )}$ & $\mathbf{4 . 2 4 ( 6 )}$ & $11.95(1)$ & $\mathbf{9 . 9 0 ( 3 )}$ & $\mathbf{5 . 4 3 ( 5 )}$ & $8.10(4)$ & 8.34 & 2.74 \\
2000 & $10.41(2)$ & $\mathbf{4 . 3 6 ( 5 )}$ & $11.95(1)$ & $9.90(3)$ & $\mathbf{2 . 5 9 ( 6 )}$ & $8.10(4)$ & 7.89 & 3.35 \\
2001 & $10.41(2)$ & $4.36(5)$ & $11.95(1)$ & $\mathbf{- 1 . 8 0 ( 6 )}$ & $\mathbf{5 . 3 6 ( 4 )}$ & $8.10(3)$ & 6.40 & 4.51 \\
2002 & $10.41(2)$ & $4.36(5)$ & $11.95(1)$ & $-1.80(6)$ & $5.36(4)$ & $\mathbf{7 . 7 5 ( 3 )}$ & 6.34 & 4.49 \\
2003 & $10.41(2)$ & $4.36(5)$ & $11.95(1)$ & $-1.80(6)$ & $5.36(4)$ & $7.75(3)$ & 6.34 & 4.49 \\
\hline
\end{tabular}

Common assumptions: $\mathrm{A}_{0}=100, \mathrm{r}=4 \%, \alpha=\delta^{*}=20 \%, \mathrm{C}=\mathrm{PV}_{0}=416.7$ and $\Gamma=10$ years.

Note: The bold numbers indicate the ITP values (= nominal net present values minus FG $^{\text {gdd* }}$ ) and the ranks led by corporate tax reforms. The ranks are shown in parentheses.

Source: Tables 1, 2 and 4; own calculations. 
Table 8 True investment promotion (TIP) effect for SMEs in the selected EU countries with $\pi=6 \%$ : investment in equipment

\begin{tabular}{|c|c|c|c|c|c|c|c|c|}
\hline & Austria & Finland & France & Germany & Ireland & UK & Mean & $\begin{array}{c}\text { Standard } \\
\text { deviation }\end{array}$ \\
\hline 1980 & $42.29(1)$ & $11.13(4)$ & $6.94(6)$ & $7.16(5)$ & $35.38(2)$ & $33.56(3)$ & 22.74 & 14.64 \\
1981 & $42.29(1)$ & $11.13(5)$ & $6.94(6)$ & $\mathbf{1 2 . 2 3 ( 4 )}$ & $35.38(2)$ & $33.56(3)$ & 23.59 & 13.84 \\
1982 & $42.29(1)$ & $11.13(5)$ & $6.94(6)$ & $12.23(4)$ & $35.38(2)$ & $33.56(3)$ & 23.59 & 13.84 \\
1983 & $42.29(1)$ & $11.13(5)$ & $6.94(6)$ & $12.23(4)$ & $\mathbf{3 6 . 5 4 ( 2 )}$ & $\mathbf{3 2 . 6 6 ( 3 )}$ & 23.63 & 13.91 \\
1984 & $42.29(1)$ & $11.13(5)$ & $6.94(6)$ & $12.23(4)$ & $36.54(2)$ & $\mathbf{2 8 . 1 3 ( 3 )}$ & 22.88 & 13.52 \\
1985 & $42.29(1)$ & $11.13(5)$ & $\mathbf{6 . 6 3 ( 6 )}$ & $12.23(4)$ & $36.54(2)$ & $28.13(3)$ & 22.83 & 13.58 \\
1986 & $42.29(1)$ & $\mathbf{9 . 4 0 ( 5 )}$ & $6.63(6)$ & $12.23(4)$ & $36.54(2)$ & $\mathbf{2 7 . 4 7 ( 3 )}$ & 22.43 & 13.80 \\
1987 & $42.29(1)$ & $9.40(5)$ & $\mathbf{6 . 1 0 ( 6 )}$ & $12.23(4)$ & $36.54(2)$ & $\mathbf{2 6 . 0 8 ( 3 )}$ & 22.11 & 13.82 \\
1988 & $42.29(1)$ & $9.40(5)$ & $6.10(6)$ & $12.23(4)$ & $36.54(2)$ & $\mathbf{2 4 . 6 0 ( 3 )}$ & 21.86 & 13.76 \\
1989 & $\mathbf{2 1 . 4 5 ( 3 )}$ & $9.40(5)$ & $\mathbf{5 . 8 9 ( 6 )}$ & $\mathbf{1 1 . 9 0 ( 4 )}$ & $36.54(1)$ & $24.60(2)$ & 18.30 & 10.46 \\
1990 & $21.45(3)$ & $\mathbf{7 . 5 7 ( 5 )}$ & $\mathbf{5 . 5 6 ( 6 )}$ & $11.90(4)$ & $\mathbf{3 4 . 7 3 ( 1 )}$ & $24.60(2)$ & 17.64 & 10.29 \\
1991 & $21.45(3)$ & $\mathbf{7 . 0 6 ( 5 )}$ & $5.56(6)$ & $11.90(4)$ & $34.73(1)$ & $24.60(2)$ & 17.55 & 10.37 \\
1992 & $21.45(2)$ & $\mathbf{5 . 9 9 ( 5 )}$ & $\mathbf{5 . 4 8 ( 6 )}$ & $11.90(3)$ & $\mathbf{7 . 8 8 ( 4 )}$ & $24.60(1)$ & 12.88 & 7.52 \\
1993 & $21.45(2)$ & $\mathbf{7 . 5 7 ( 5 )}$ & $5.48(6)$ & $\mathbf{1 1 . 4 0 ( 3 )}$ & $7.88(4)$ & $24.60(1)$ & 13.06 & 7.31 \\
1994 & $\mathbf{2 4 . 6 1 ( 1 )}$ & $7.57(5)$ & $\mathbf{1 2 . 7 6 ( 2 )}$ & $11.40(3)$ & $7.88(4)$ & $\mathbf{4 . 3 7 ( 6 )}$ & 11.43 & 6.49 \\
1995 & $24.61(1)$ & $7.57(5)$ & $12.76(2)$ & $11.40(3)$ & $\mathbf{7 . 5 8 ( 4 )}$ & $\mathbf{4 . 2 2 ( 6 )}$ & 11.36 & 6.55 \\
1996 & $24.61(1)$ & $\mathbf{8 . 3 4 ( 4 )}$ & $12.76(2)$ & $11.40(3)$ & $7.58(5)$ & $\mathbf{4 . 0 7}(\mathbf{6 )}$ & 11.46 & 6.51 \\
1997 & $24.61(1)$ & $8.34(4)$ & $12.76(2)$ & $11.40(3)$ & $\mathbf{7 . 2 0 ( 5 )}$ & $\mathbf{3 . 7 6 ( 6 )}$ & 11.35 & 6.60 \\
1998 & $24.61(1)$ & $8.34(5)$ & $12.76(2)$ & $11.40(3)$ & $\mathbf{6 . 5 9 ( 6 )}$ & $\mathbf{9 . 1 7 ( 4 )}$ & 12.15 & 5.92 \\
1999 & $\mathbf{9 . 5 3 ( 3 )}$ & $\mathbf{4 . 8 0 ( 6 )}$ & $12.76(1)$ & $\mathbf{1 0 . 6 8 ( 2 )}$ & $\mathbf{5 . 8 6}(5)$ & $9.17(4)$ & 8.80 & 2.72 \\
2000 & $9.53(3)$ & $\mathbf{4 . 9 3 ( 5 )}$ & $12.76(1)$ & $10.68(2)$ & $\mathbf{2 . 7 1 ( 6 )}$ & $9.17(4)$ & 8.30 & 3.43 \\
2001 & $9.53(2)$ & $4.93(4)$ & $12.76(1)$ & $-\mathbf{2 . 4 8 ( 6 )}$ & $\mathbf{5 . 9 5 ( 3 )}$ & $9.17(3)$ & 6.64 & 4.81 \\
2002 & $9.53(2)$ & $4.93(5)$ & $12.76(1)$ & $-2.48(6)$ & $5.95(4)$ & $\mathbf{8 . 7 6 ( 3 )}$ & 6.58 & 4.78 \\
2003 & $9.53(2)$ & $4.93(5)$ & $12.76(1)$ & $-2.48(6)$ & $5.95(3)$ & $8.76(3)$ & 6.58 & 4.78 \\
\hline
\end{tabular}

Common assumptions: $\mathrm{A}_{0}=100, \mathrm{r}=4 \%, \alpha=\delta^{*}=20 \%, \mathrm{C}=\mathrm{PV}_{0}=416.7$ and $\Gamma=10$ years.

Note: The bold numbers indicate the ITP values (= nominal net present values minus FG $^{\text {gdd* }}$ ) and the ranks led by corporate tax reforms. The ranks are shown in parentheses.

Source: Tables 1, 2 and 5; own calculations.

In addition one can well identify different ITP development types among the investigated EU nations. Austria and Finland belong to the same country group for which those values declined in the course of time but with significant fluctuations in the 1990s. A drop of TIP value at the end of 1990s is also comparable in these two countries (Figures 1), although the decrease is mainly triggered by the generosity reduction of $\beta$ from $20 \%$ to $9 \%$ in Austria and $\delta$ from $30 \%$ to $25 \%$ in Finland.

Ireland and the UK also had a quite similar TIP development pattern in the past. A rapid reduction of its value took place in Ireland in 1992 and two years later also in the UK (Figure 2). The major reason for this significant change was the substitution of free depreciation to less generous straight-line depreciation (with 7 years of tax life) in Ireland and to geometric-degressive depreciation (with $\delta=25 \%$ ) in the UK, while t remained unchanged in both reform years (40\% in Ireland and 33\% in the UK). In the period before 
as well as after these 'big bang' reform years mentioned above the TIP values remained stable and developed comparably in both countries.

The model simulation also suggests that the SME-specific lower corporate tax rates can lead - with the given uniform depreciation rule - to less significant investment promotion effects than is the case with the normal statutory rates, since the reduction of $t$ also causes a decrease in tax savings (Table 9). In spite of the lower tax rates, the TIP values for SMEs were smaller than those for large firms in the UK in the period between 1980 and 1997. Yet the combination of lower tax rate with the more generous SME-specific accelerated depreciation (instead of a geometric-degressive one for large firms) has created larger scale promotion effects since 1998.

Table 9 Comparison of true investment promotion (TIP) effect between SMEs and large firms in the UK: investment in equipment

\begin{tabular}{|l|c|c|c|c|c|c|}
\hline & \multicolumn{5}{|c|}{ SMEs } & \multicolumn{3}{c|}{ Large firms } \\
\cline { 2 - 6 } & $\pi=2 \%$ & $\pi=4 \%$ & $\pi=6 \%$ & $\pi=2 \%$ & $\pi=4 \%$ & $\pi=6 \%$ \\
\hline 1980 & 22.46 & 28.32 & 33.56 & 24.19 & 30.79 & 36.82 \\
1981 & 22.46 & 28.32 & 33.56 & 24.19 & 30.79 & 36.82 \\
1982 & 22.46 & 28.32 & 33.56 & 24.19 & 30.79 & 36.82 \\
1983 & 21.92 & 27.61 & 32.66 & 24.08 & 30.62 & 36.54 \\
1984 & 19.11 & 23.91 & 28.13 & 23.50 & 30.30 & 35.38 \\
1985 & 19.11 & 23.91 & 28.13 & 22.46 & 29.51 & 33.56 \\
1986 & 18.67 & 23.36 & 27.47 & 20.99 & 26.36 & 31.13 \\
1987 & 17.78 & 22.20 & 26.08 & 20.99 & 26.36 & 31.13 \\
1988 & 16.82 & 20.98 & 24.60 & 20.99 & 26.36 & 31.13 \\
1989 & 16.82 & 20.98 & 24.60 & 20.99 & 26.36 & 31.13 \\
1990 & 16.82 & 20.98 & 24.60 & 20.65 & 25.92 & 30.57 \\
1991 & 16.82 & 20.98 & 24.60 & 20.65 & 25.92 & 30.57 \\
1992 & 16.82 & 20.98 & 24.60 & 20.29 & 25.44 & 30.00 \\
1993 & 16.82 & 20.98 & 24.60 & 20.29 & 25.44 & 30.00 \\
1994 & 3.29 & 3.87 & 4.37 & 3.97 & 4.79 & 5.44 \\
1995 & 3.20 & 3.75 & 4.22 & 3.97 & 4.79 & 5.44 \\
1996 & 3.16 & 3.62 & 4.07 & 3.97 & 4.79 & 5.44 \\
1997 & 2.88 & 3.35 & 3.76 & 3.97 & 4.79 & 5.44 \\
1998 & 6.75 & 8.10 & 9.17 & 3.80 & 4.58 & 5.19 \\
1999 & 6.75 & 8.10 & 9.17 & 3.72 & 4.47 & 5.06 \\
2000 & 6.75 & 8.10 & 9.17 & 3.72 & 4.47 & 5.06 \\
2001 & 6.75 & 8.10 & 9.17 & 3.72 & 4.47 & 5.06 \\
2002 & 6.47 & 7.75 & 8.76 & 3.72 & 4.47 & 5.06 \\
2003 & 6.47 & 7.75 & 8.76 & 3.72 & 4.47 & 5.06 \\
\hline
\end{tabular}

Common assumptions: $\mathrm{A}_{0}=100, \mathrm{r}=4 \%, \alpha=\delta^{*}=20 \%, \mathrm{C}=\mathrm{PV}_{0}=416.7$ and $\Gamma=10$ years. Source: Tables 1, 2 and 6-8; own calculations.

France and Germany are countries whose individual TIP development patterns are quite unique. For example, French TIP values remained quite stable at a lower level until 1993 but at a higher level since 1994. A fast jump of TIP in 1994 was led by a $\delta$ increase from $25 \%$ to $37.5 \%$ while maintaining $t=33 \%$. German TIP values grew rapidly thanks to the 
increase in $\delta$ from $25 \%$ (1980) to $30 \%$ (1981) by given $t=56 \%$. Thereafter the TIP value remained quite constant, which however sank to the level below zero in 2001, due to the simultaneous reduction of $\mathrm{t}$ from $40 \%$ to $25 \%$ and the change of geometricdegressive depreciation with $\delta=30 \%$ to straight-line one with $\Gamma=10$ years (Figure 3 ).

Figure 1

True investment promotion effect for SMEs shown by nominal NPV: Austria and Finland

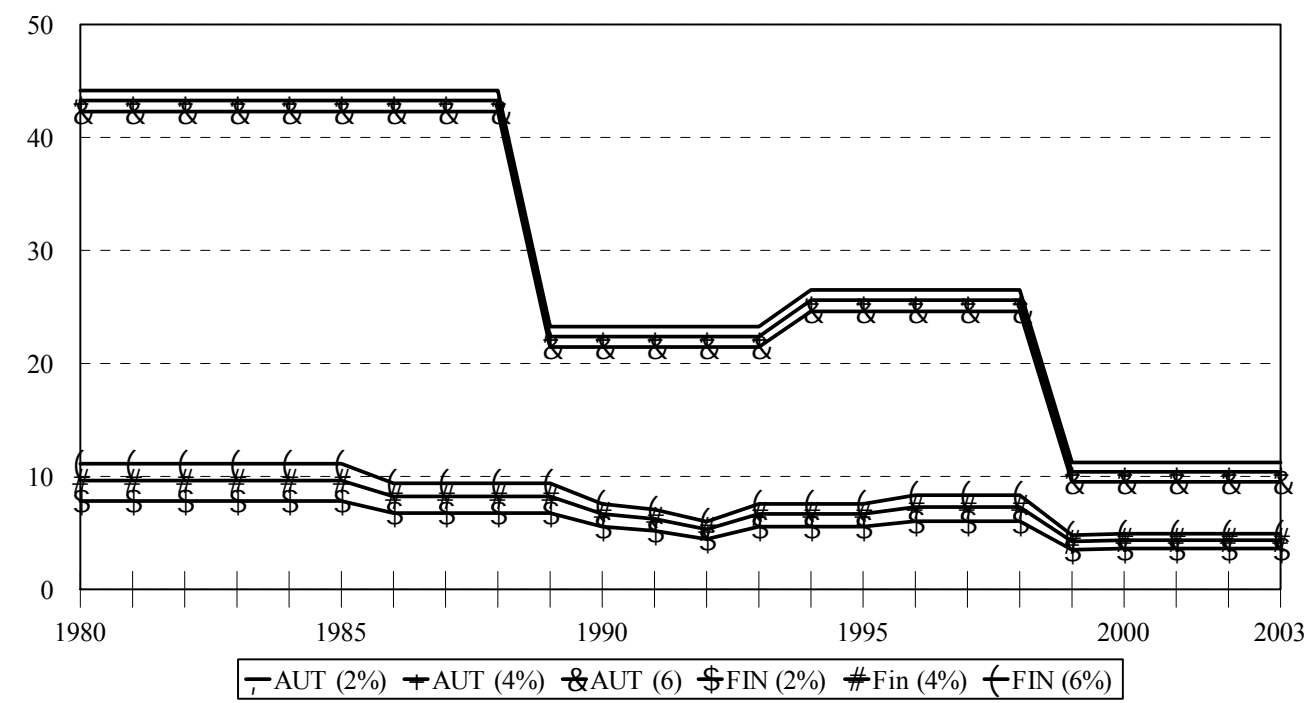

Source: Tables 6-8

Figure 2

True investment promotion effect for SMEs shown by nominal NPV: Ireland and UK

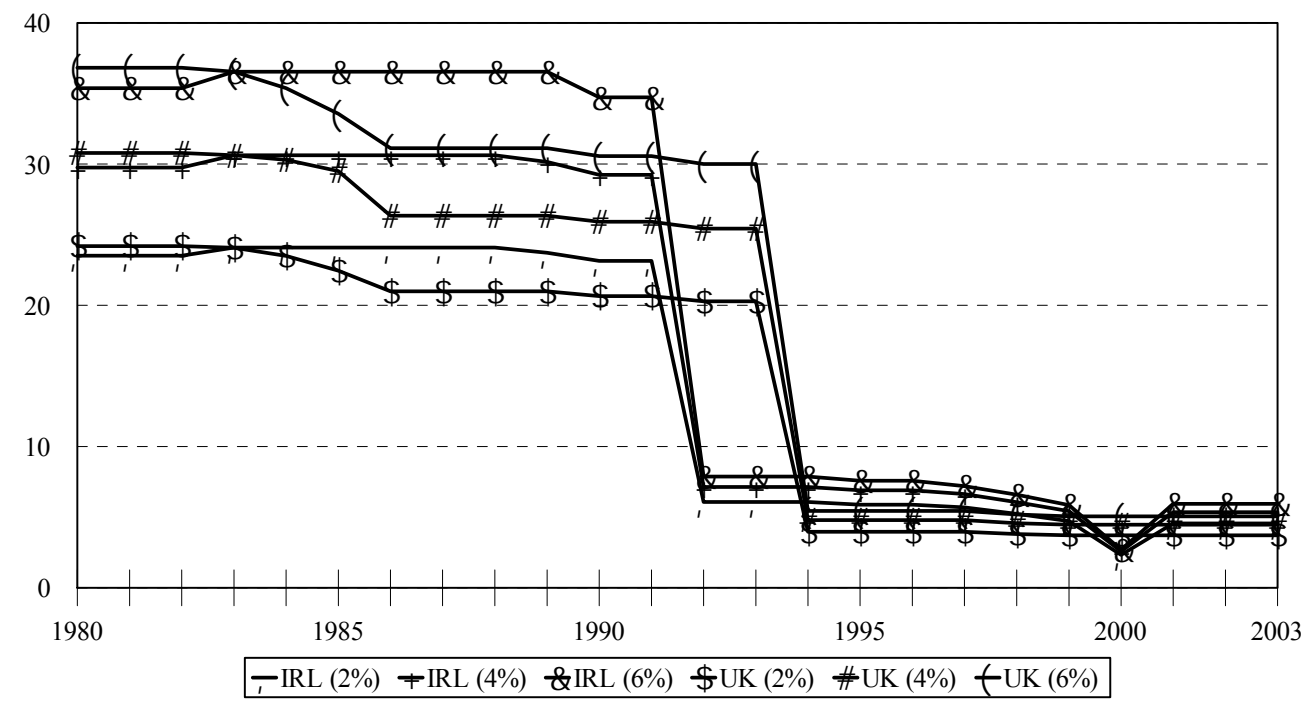

Source: Tables 6-8 
Figure 3

True investment promotion effect for SMEs shown by nominal NPV: France and Germany

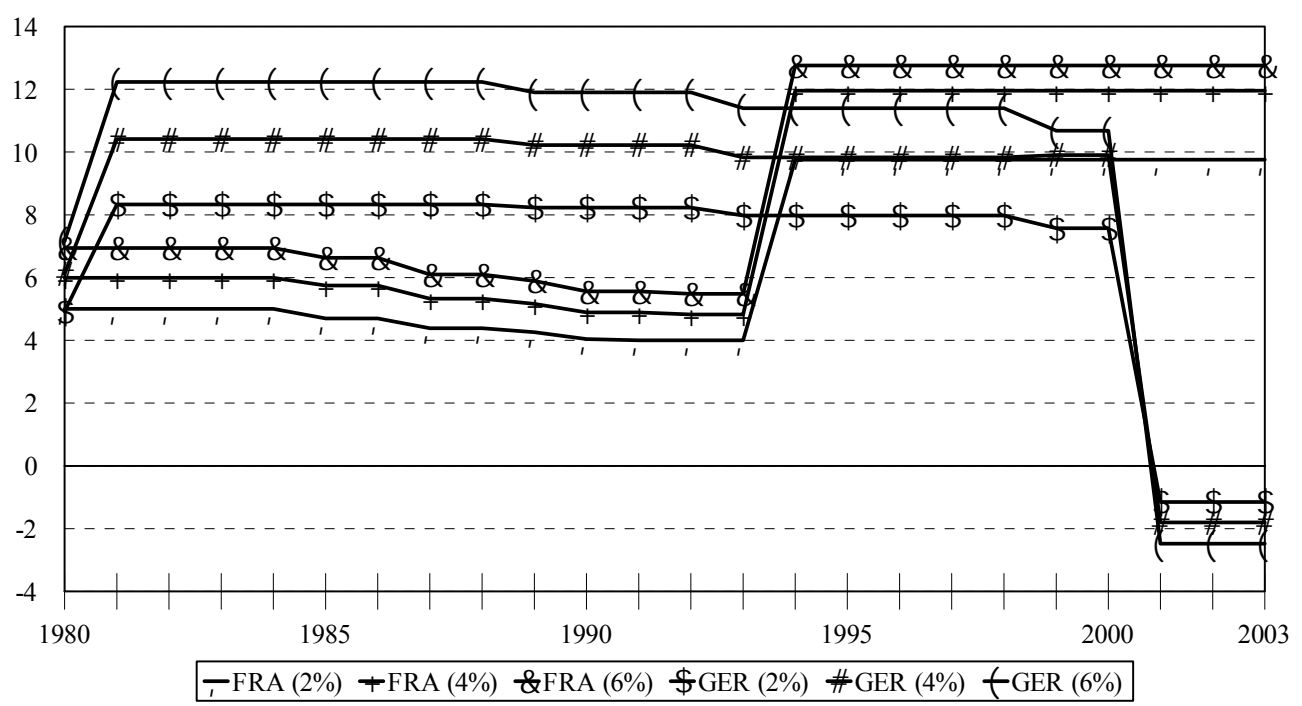

Source: Tables 6-8

The TIP values of individual countries are also compared in terms of international rank of competitive position as shown in the parentheses of Tables 6 to 8 . With $\pi=2 \%$ the Austrian corporate tax system with investment tax allowance maintained the leading position throughout all of the considered years. Under the assumption of $\pi=4 \%$ and $6 \%$, however, the country's first rank was shared with other nations like Ireland (1989-91) and France (1999-2003). A number of corporate tax reforms did not change the ranking much. This fact applies most apparently for those reforms - in particular the reduction of $\mathrm{t}$ - carried out in Finland (1986, 1990-3, 1996 and 1999), Germany (1989, 1993 and 1999), France (1985, 1987, 1989-90 and 1992), Ireland (1997), and the UK (1983-84, 1986-88, 1995-96 and 2002). Despite numerous amendments of the corporate tax system, the competitive position of individual countries remained less favourable in these reform years.

On the other hand, some significant consequences of reforms of a positive and also a negative kind are observed in France, Ireland and the UK. As illustrated above, the increase of $\delta$ from $25 \%$ to $37.5 \%$ in 1994 (while keeping $t=33.33 \%$ ) improved France's position from the last to the second. Irish 1992 big bang reform which reduced $t$ from $43 \%$ to $40 \%$ and switched the traditional free depreciation to straight-line depreciation (with seven years of tax life), made the country's competitive position worse off from the second to the fourth. A more serious negative consequence was led by British 1994 reform: the change from free to geometric-degressive depreciation $(\delta=25 \%)$ in 1995 - but maintaining specific $\mathrm{t}=25 \%$ for SMEs - demolished the country's position. The further reduction 
of $t$ to $20 \%$ and the introduction of accelerated depreciation with $\sigma=30 \%$ in 1999 was able to offset this disadvantage to a certain extent (from the last to the third rank).

\section{Conclusion}

For the selected six EU countries this study examines the effects of corporate tax reforms on SMEs' investment decisions implemented since the beginning of the 1980s. These reforms entailed lower statutory tax rates accompanied by the reduction of generous tax depreciation provisions. Among them the UK has traditionally had reduced tax rates for SMEs. Under the specific assumptions of relevant parameters, the tax incentive and/or burden on investment activity is measured in terms of nominal net present value (NPV).

Major findings of the model simulation can be summarised as follows:

- The application of the historical cost accounting system (instead of the current cost accounting method) in the inflationary economy when calculating tax depreciation amounts creates the fictitious gain in nominal NPV ( $\mathrm{FG}^{\text {gdd* }}$ ), although the equity of tax depreciation and TED — the important condition for tax neutrality — is assumed. In general this type of gain decreased gradually in the period between 1980-2003, since t and $\pi$ continued to sink in the investigated EU nations.

- A down-sloping development is also observed for the TIP value (= nominal NPV with tax depreciation scheme minus $\mathrm{FG}^{\text {gdd* }}$ ). France with an increasing trend was the only exception. In addition, different nation groups are identified, based on the TIP values for SMEs in the individual countries. A clear similarity of the TIP development pattern prevails in Austria and Finland, on the one hand, as well as in Ireland and the UK, on the other. Apart from France, Germany also had a unique feature.

- Since SMEs are the majority of firms in the advanced countries, their competitiveness significantly affects the competitiveness of an individual nation's economy as a whole. According to the international ranking constructed also on the basis of annual TIP values, the Austrian investment tax allowance system provided the most favourable condition for SMEs in the survey years, when $\pi$ is $2 \%$. Yet the country shared its first position with Ireland and France if the same rate increases to $4 \%$ or $6 \%$. A series of corporate tax reforms made in Germany and Finland were not able to enhance their low ranks much. In contrast to the positive reform consequence like the French case in 1994, Irish and British tax policy interventions, which replaced free depreciation, destroyed their leading competitive position in the first half of 1990s. 


\section{References}

Alvarez, L., V. Kanniainen and J. Södersten (2000), Why Is the Corporation Tax Not Neutral?, Finanzarchiv 56, 285-309.

Atkinson, A. B. and J. E. Stiglitz (1980), Lectures on Public Economics, London: McGraw-Hill.

Auerbach, A. J. (1983), Corporate Taxation in the United States, Brookings Papers on Economic Activity 2, 451-513.

Chen, D., F. C. Lee and J. Mintz (2002), Taxation, SMEs and Entrepreneuship, STI Working Paper 2002/9, OECD, Paris.

Cohen, D. and K. A. Hassett (1999), Inflation, Taxes and Durability of Capital, National Tax Journal 52, 91-98.

Coyne, E. J. (1995), Proposed Analytical Model for FDI Attraction Into Developing Countries, Essays in International Business 1, The International Business Center, College of Professional Studies, University of the District of Columbia, Washington, D.C.

Devereux, P. M. and R. Griffith (2003), Evaluating Tax Policy for Location Decisions, International Tax and Public Finance 10, 107-126.

Devereux, P. M., R. Griffith and A. Klemm (2002), Corporate Income Tax Reforms and International Tax Competition, Economic Policy 35, 451-495.

Devereux, P. M., R. Griffith and A. Klemm (2004), Why Has the UK Corporation Tax Raised So Much Revenue?, Fiscal Studies 25, 367-388.

Evans, M. K. (1983), The Truth about Supply-Side Economics, New York: Basic Books.

Feldstein, M. S. (1979), Adjusting Depreciation in an Inflationary Economy: Indexing versus Acceleration, NBER Working Paper Series 395, Cambridge, Mass.

Feldstein, M. S. and L. Summers (1979), Inflation and the Taxation of Capital Income in the Corporate Sector, National Tax Journal 32, 445-471.

Gordon, R., L. Kalambokidis and J. Slemrod (2004), A New Summary Measure of the Effective Tax Rate on Investment, in: Sørensen, P. B. (ed.), Measuring the Tax Burden on Capital and Labor, Cambridge: MIT Press, 99-128.

Hall, R. E. and D. Jorgenson (1967), Tax Policy and Investment Behavior, American Economic Review 57, 391-414.

Haufler, A. and G. Schjelderup (2000), Corporate Tax System and Cross Country Profit Shifting, Oxford Economic Papers 52, 306-325.

Hendricks, K., R. Amit and D. Whistler (1997), Business Taxation of Small and Medium-sized Enterprises in Canada, Department of Finance Working Paper 97-11, Government of Canada, Ottawa. 
Hulten, C. R. and F. C. Wykoff (1996), Issues in the Measurement of Economic Depreciation: Introductory Remarks, Economic Inquiry 34, 10-23.

Janeba, E. (1995), Corporate Income Tax Competition, Double Taxation, and Foreign Direct Investment, Journal of Public Economics 56, 311-325.

Keen, M. J. (1991), Corporation Tax, Foreign Direct Investment and the Single Market, in: Winters, L. A. and A. J. Venables (eds.), The Impact of 1992 on European Trade and Industry, Cambridge: Cambridge University Press.

King, M. A. and D. Fullerton (1984), The Taxation of Income from Capital: A Comparative Study of the United States, the United Kingdom, Sweden, and West Germany, Chicago: University of Chicago Press.

Nam, C. W. and D. M. Radulescu (2004), Do Corporate Tax Concessions Really Matter for the Success of Free Economic Zones, Economics of Planning, forthcoming.

Nam, C. W. and D. M. Radulescu (2005), The Role of Tax Depreciation for Investment Decisions: A Comparison of European Transition Countries, Eastern European Economics, forthcoming.

Ott, M. (1984), Depreciation, Inflation and Investment Incentives: The Effects of the Tax Acts 1981 and 1982, Monthly Review of Federal Reserve Bank of St. Louis, November 1984, 17-30.

Razin, A., E. Sadka and C. W. Nam (2005), The Decline of the Welfare State: Demography and Globalization, Cambridge: MIT Press.

Samuelson, P. A. (1964), Tax Deductibility of Economic Depreciation to Ensure Invariant Valuation, Journal of Political Economy 72, 604-606.

Sinn, H. W. (1987), Capital Income Taxation and Resource Allocation, Amsterdam: North-Holland.

Sørensen, P. B. (2004), Measuring Taxes on Capital and Labor: An Overview of Methods and Issues, in: Sørensen, P. B. (ed.), Measuring the Tax Burden on Capital and Labor, Cambridge: MIT Press, 1-33. 


\section{CESifo Working Paper Series}

(for full list see www.cesifo-group.de)

1413 Gil S. Epstein and Shmuel Nitzan, Lobbying and Compromise, February 2005

1414 Marcel F. M. Canoy, Jan C. van Ours and Frederick van der Ploeg, The Economics of Books, February 2005

1415 Eric A. Hanushek and Ludger Wößmann, Does Educational Tracking Affect Performance and Inequality? Differences-in-Differences Evidence across Countries, February 2005

1416 George Kapetanios and M. Hashem Pesaran, Alternative Approaches to Estimation and Inference in Large Multifactor Panels: Small Sample Results with an Application to Modelling of Asset Returns, February 2005

1417 Samuel Mühlemann, Jürg Schweri, Rainer Winkelmann and Stefan C. Wolter, A Structural Model of Demand for Apprentices. February 2005

1418 Giorgio Brunello and Lorenzo Rocco, Educational Standards in Private and Public Schools, February 2005

1419 Alex Bryson, Lorenzo Cappellari and Claudio Lucifora, Why so Unhappy? The Effects of Unionisation on Job Satisfaction, March 2005

1420 Annalisa Luporini, Relative Performance Evaluation in a Multi-Plant Firm, March 2005

1421 Giorgio Bellettini and Carlotta Berti Ceroni, When the Union Hurts the Workers: A Positive Analysis of Immigration Policy, March 2005

1422 Pieter Gautier, Michael Svarer and Coen Teulings, Marriage and the City, March 2005

1423 Ingrid Ott and Stephen J. Turnovsky, Excludable and Non-Excludable Public Inputs: Consequences for Economic Growth, March 2005

1424 Frederick van der Ploeg, Back to Keynes?, March 2005

1425 Stephane Dees, Filippo di Mauro, M. Hashem Pesaran and L. Vanessa Smith, Exploring the International Linkages of the Euro Area: a Global VAR Analysis, March 2005

1426 Hans Pitlik, Friedrich Schneider and Harald Strotmann, Legislative Malapportionment and the Politicization of Germany’s Intergovernmental Transfer System, March 2005

1427 Konstantinos Angelopoulos and Apostolis Philippopoulos, The Role of Government in Anti-Social Redistributive Activities, March 2005

1428 Ansgar Belke and Daniel Gros, Asymmetries in the Trans-Atlantic Monetary Policy Relationship: Does the ECB follow the Fed?, March 2005 
1429 Sören Blomquist and Luca Micheletto, Optimal Redistributive Taxation when Government’s and Agents’ Preferences Differ, March 2005

1430 Olof Åslund and Peter Fredriksson, Ethnic Enclaves and Welfare Cultures - QuasiExperimental Evidence, March 2005

1431 Paul De Grauwe, Roberto Dieci and Marianna Grimaldi, Fundamental and NonFundamental Equilibria in the Foreign Exchange Market. A Behavioural Finance Framework, March 2005

1432 Peter Egger, Stefan Gruber, Mario Larch and Michael Pfaffermayr, Knowledge-Capital Meets New Economic Geography, March 2005

1433 George Economides and Apostolis Philippopoulos, Should Green Governments Give Priority to Environmental Policies over Growth-Enhancing Policies?, March 2005

1434 George W. Evans and Seppo Honkapohja, An Interview with Thomas J. Sargent, March 2005

1435 Helge Berger and Volker Nitsch, Zooming Out: The Trade Effect of the Euro in Historical Perspective, March 2005

1436 Marc-Andreas Muendler, Rational Information Choice in Financial Market Equilibrium, March 2005

1437 Martin Kolmar and Volker Meier, Intra-Generational Externalities and InterGenerational Transfers, March 2005

1438 M. Hashem Pesaran and Takashi Yamagata, Testing Slope Homogeneity in Large Panels, March 2005

1439 Gjermund Nese and Odd Rune Straume, Industry Concentration and Strategic Trade Policy in Successive Oligopoly, April 2005

1440 Tomer Blumkin and Efraim Sadka, A Case for Taxing Education, April 2005

1441 John Whalley, Globalization and Values, April 2005

1442 Denise L. Mauzerall, Babar Sultan, Namsoug Kim and David F. Bradford, Charging $\mathrm{NO}_{x}$ Emitters for Health Damages: An Exploratory Analysis, April 2005

1443 Britta Hamburg, Mathias Hoffmann and Joachim Keller, Consumption, Wealth and Business Cycles in Germany, April 2005

1444 Kohei Daido and Hideshi Itoh, The Pygmalion Effect: An Agency Model with Reference Dependent Preferences, April 2005

1445 John Whalley, Rationality, Irrationality and Economic Cognition, April 2005

1446 Henning Bohn, The Sustainability of Fiscal Policy in the United States, April 2005 
1447 Torben M. Andersen, Is there a Role for an Active Fiscal Stabilization Policy? April 2005

1448 Hans Gersbach and Hans Haller, Bargaining Power and Equilibrium Consumption, April 2005

1449 Jerome L. Stein, The Transition Economies: A NATREX Evaluation of Research, April 2005

1450 Raymond Riezman, John Whalley and Shunming Zhang, Metrics Capturing the Degree to which Individual Economies are Globalized, April 2005

1451 Romain Ranciere, Aaron Tornell and Frank Westermann, Systemic Crises and Growth, April 2005

1452 Plutarchos Sakellaris and Focco W. Vijselaar, Capital Quality Improvement and the Sources of Growth in the Euro Area, April 2005

1453 Kevin Milligan and Michael Smart, Regional Grants as Pork Barrel Politics, April 2005

1454 Panu Poutvaara and Andreas Wagener, To Draft or not to Draft? Efficiency, Generational Incidence, and Political Economy of Military Conscription, April 2005

1455 Maurice Kugler and Hillel Rapoport, Skilled Emigration, Business Networks and Foreign Direct Investment, April 2005

1456 Yin-Wong Cheung and Eiji Fujii, Cross-Country Relative Price Volatility: Effects of Market Structure, April 2005

1457 Margarita Katsimi and Thomas Moutos, Inequality and Relative Reliance on Tariffs: Theory and Evidence, April 2005

1458 Monika Bütler, Olivia Huguenin and Federica Teppa, Why Forcing People to Save for Retirement may Backfire, April 2005

1459 Jos Jansen, The Effects of Disclosure Regulation of an Innovative Firm, April 2005

1460 Helge Bennmarker, Kenneth Carling and Bertil Holmlund, Do Benefit Hikes Damage Job Finding? Evidence from Swedish Unemployment Insurance Reforms, May 2005

1461 Steffen Huck, Kai A. Konrad and Wieland Müller, Merger without Cost Advantages, May 2005

1462 Louis Eeckhoudt and Harris Schlesinger, Putting Risk in its Proper Place, May 2005

1463 Hui Huang, John Whalley and Shunming Zhang, Trade Liberalization in a Joint Spatial Inter-Temporal Trade Model, May 2005

1464 Mikael Priks, Optimal Rent Extraction in Pre-Industrial England and France - Default Risk and Monitoring Costs, May 2005 
1465 François Ortalo-Magné and Sven Rady, Heterogeneity within Communities: A Stochastic Model with Tenure Choice, May 2005

1466 Jukka Pirttilä and Sanna Tenhunen, Pawns and Queens Revisited: Public Provision of Private Goods when Individuals make Mistakes, May 2005

1467 Ernst Fehr, Susanne Kremhelmer and Klaus M. Schmidt, Fairness and the Optimal Allocation of Ownership Rights, May 2005

1468 Bruno S. Frey, Knight Fever - Towards an Economics of Awards, May 2005

1469 Torberg Falch and Marte Rønning, The Influence of Student Achievement on Teacher Turnover, May 2005

1470 John Komlos and Peter Salamon, The Poverty of Growth with Interdependent Utility Functions, May 2005

1471 Hui Huang, Yi Wang, Yiming Wang, John Whalley and Shunming Zhang, A Trade Model with an Optimal Exchange Rate Motivated by Current Discussion of a Chinese Renminbi Float, May 2005

1472 Helge Holden, Lars Holden and Steinar Holden, Contract Adjustment under Uncertainty, May 2005

1473 Kai A. Konrad, Silent Interests and All-Pay Auctions, May 2005

1474 Ingo Vogelsang, Electricity Transmission Pricing and Performance-Based Regulation, May 2005

1475 Spiros Bougheas and Raymond Riezman, Trade and the Distribution of Human Capital, June 2005

1476 Vesa Kanniainen, Seppo Kari and Jouko Ylä-Liedenpohja, The Start-Up and Growth Stages in Enterprise Formation: The "New View" of Dividend Taxation Reconsidered, June 2005

1477 M. Hashem Pesaran, L. Vanessa Smith and Ron P. Smith, What if the UK had Joined the Euro in 1999? An Empirical Evaluation Using a Global VAR, June 2005

1478 Chang Woon Nam and Doina Maria Radulescu, Effects of Corporate Tax Reforms on SMEs’ Investment Decisions under the Particular Consideration of Inflation, June 2005 